\title{
sciendo
}

\author{
Current Issues in Pharmacy and Medical Sciences \\ Formerly ANNALES UNIVERSITATIS MARIAE CURIE-SKLODOWSKA, SECTIO DDD, PHARMACIA

\section{Anticholinesterase and antioxidant activities of foliar extract from a tropical species: Psidium guajava L. (Myrtaceae) grown in Algeria}

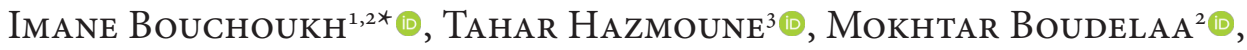 \\ Chawki Bensouici ${ }^{4}{ }^{\circ}$, Amar Zellagui $^{5}$ (우
}

\footnotetext{
${ }^{1}$ Department of Biology and Plant Ecology, Faculty of Sciences of Nature and Life, Mentouri University, Constantine 1, 25000, Algeria

${ }^{2}$ Department of Biology, Faculty of Sciences, Badji Mokhtar University, Annaba, 23000, Algeria

${ }^{3}$ Laboratory for the Optimization of Agricultural Production and Arboriculture in the Subhumid Zone, Department of Agronomy, University 20 Aout 1955, Skikda, 21000, Algeria

${ }^{4}$ Biotechnology Research Center, Ali Mendjli, Constantine, 25000, Algeria

${ }^{5}$ Laboratory of Biomolecules and Plant Breeding, Larbi Ben M’hidi University, Oum El Bouaghi, 04000, Algeria
}

\section{ARTICLE INFO}

Received 20 January 2019

Accepted 11 March 2019

\section{Keywords:}

Psidium guajava, antioxidant activity, antiacetylcholinesterase, antibutyrylcholinesterase, phenolic compounds, Alzheimer disease.

\begin{abstract}
Guava (Psidium guajava L.) is a fruit tree largely used in folk medicine in tropical and subtropical areas. This exotic species was introduced in a botanical garden in the northeast of Algeria in the 1950's. The aim of this study is to estimate, for the first time, the antioxidant and anticholinesterase activities of chloroform, ethyl acetate and n-butanol extracts of $P$. guajava growing in Algeria. Six antioxidant assays were tested, results showed very important efficiency in free radical scavenging, reducing power and $\beta$-carotene bleaching of tested extracts. Values of $\mathrm{IC}_{50}$ or $\mathrm{A}_{0.5}$ of some samples were lower than those of standards. With regard to anticholinesterase activity, the inhibitory of both acetylcholinesterase (AChE) and butyrylcholinesterase (BChE) was investigated. The extracts exhibited interesting capacity to inhibit these enzymes with low values of $\mathrm{IC}_{50}$ and even less than that of galanthamine. These activities were correlated with total phenolic content which was more important compared to the one found in extracts from trees growing in tropical and subtropical region. This could be due to resistance and adaptation of P. guajava grown in Algeria. The data obtained suggest the use of bioactive compounds from $P$. guajava leaves as antioxidant and drugs for symptomatic treatment of Alzheimer disease.
\end{abstract}

\section{INTRODUCTION}

Oxidative stress is defined as a state in which oxidation exceeds the antioxidant systems in the body following a loss in the balance between them [1]. Antioxidants are substances that may protect cells from the damage caused by unstable molecules known as ROS (reactive oxygen species) and by free radicals [2]. The latter are implied in the etiology of a large number of pathologies that are now regarded as major problems of public health. Among others, we can mention arthritis, asthma, rheumatisms, nephritides, cancers, atherosclerosis, sweetened diabetes, inflammatory lesions, diseases with immunosuppression, metabolic disorders and

\footnotetext{
* Corresponding authors

imen.bouchoukh@umc.edu.dz
}

Alzheimer's diseases [3]. In the last 30 years, Alzheimer's disease $(\mathrm{AD})$ has become the most common neurodegenerative disease. It is the cause of $60-70 \%$ of all cases of dementia [4]. Acetylcholine (ACh) is the most abundant neurotransmitter in the body and the principal neurotransmitter in the brain that is responsible for cholinergic transmission. Cholinesterases (ChE) constitute a group of esterases that hydrolyse choline esters at a higher rate than other esters, provided that the hydrolysis rates are compared at optimum and controlled conditions [5]. Some active substances are used to stop Alzheimer's development, including galanthamine (Alkaloid). Flavonoids and phenolic acids are the most important groups of secondary metabolites considered as good sources of natural antioxidants and anticholinesterase activities in human diets [6]. 
Myrtaceae is one of the plant families that have been widely studied for their antioxidant activity, and many species belonging to this family have strong activity [7]. This family of dicotyledonous plants is composed of 140 genera and 3400 species distributed mainly in the tropical and subtropical region of the world [8]. The genus Psidium includes around 70 species distributed in the American and Asian tropics [9]. Psidium fruits are a potential source of phytochemicals for which many bioactivities have been proved. Carotenoids, phenolic compounds, and triterpenoids are the main phytochemicals characterized in leaves and fruits of this genus [10]. Psidium guajava L., commonly known as guava, is a tropical plant that is native to South America [11]. This fruit tree is an important food crop and medicinal plant in tropical and subtropical countries of Asia, and it is also largely used as food and in traditional medicine in other parts of the world. Many people use leaf decoctions of $P$. guajava for its antimicrobial and antispasmodic properties in the treatment of dysentery and diarrhea [12].

Several exotic species of tropical origin have been introduced into the botanical garden of the Ancient Institute of Agriculture of Skikda in Northeast Algeria and have perfectly been acclimatized. Among these species is Psidium guajava L. - introduced in 1952 [13].

Studies on antioxidant activity from the leaves of $P$. guajava remain limited and there are no available data about this species in Algeria. The main aim of the present study is to evaluate the antioxidant activity and inhibition of cholinesterase of leaf extracts from this important species of the family of Myrtaceae.

\section{MATERIALS AND METHODS}

\section{Plant material}

Leaves of Psidium guajava L. were collected, in May 2018, from the botanical garden of the Ancient Institute of Agriculture of Skikda in the northeast of Algeria. Species were identified by Chalabi, agronomist from the University of Skikda and an expert in exotic species cultivated and preserved at the botanical garden. A voucher specimen was deposited in our laboratory. Leaves were washed with distilled water and dried at room temperature for twenty days while under shade.

\section{Preparation of extracts}

Powdered leaves of P. guajava $(50 \mathrm{~g})$ were macerated with $300 \mathrm{ml}$ of methanol /water $(70 \mathrm{v} / 30 \mathrm{v})$ at room temperature for 72 hours $(3 \times 24 \mathrm{~h})$. After filtration, the solvent was evaporated under reduced pressure and temperature. The residue was dissolved in $200 \mathrm{ml}$ of distilled water and extracted with $200 \mathrm{ml}$ of one of three solvents: Chloroform $\left(\mathrm{CHCl}_{3}\right)$, Ethyl acetate $\left(\mathrm{C}_{4 \mathrm{H} 802}\right)$ and $n$-butanol $\left(\mathrm{C}_{4 \mathrm{H} 10 \mathrm{O}}\right)$, successively. The organic solutions were evaporated under reduced pressure and temperature to obtain the three extracts: Chloroform $(3,82 \mathrm{~g})$, Ethyl acetate $(20,05 \mathrm{~g})$, n-butanol $(32,73 \mathrm{~g})$. Crude extracts were preserved at $4{ }^{\circ} \mathrm{C}$.

\section{Total phenolic content}

The total phenolic content was determined by using the reagent of Folin-Ciocalteu [14], according to a method of microplate described par Muller and al. [15]. Herein, $20 \mu 1$ of sample (1 mg extract/1 $1 \mathrm{ml}$ methanol) were blended with $100 \mu \mathrm{l}$ of Folin-Ciocalteu reagent (1:10) and $75 \mu \mathrm{l}$ of sodium carbonate solution (7,5\%). The microplate was incubated two hours at room temperature in darkness. Absorbance at $765 \mathrm{~nm}$ was measured by using the microplate reader. The total phenolic content was evaluated as micrograms of gallic acid equivalents per milligrams of extract.

\section{Total flavonoids content}

Total flavonoids content was determined by the method of Topçu et al. [16] with some modification to adapt it to microplate. Briefly, $130 \mu \mathrm{l}$ of methanol were added to 50 $\mu \mathrm{l}$ of sample ( $1 \mathrm{mg}$ extract/ $1 \mathrm{ml}$ methanol). Subsequently, $10 \mu 1$ of $1 \mathrm{M}$ potassium acetate $\left(\mathrm{CH}_{3} \mathrm{COOK}\right)$ and $10 \mu \mathrm{l}$ of $10 \%$ aluminum nitrate $\left(\mathrm{Al}\left(\mathrm{NO}_{3}\right)_{2}, 9 \mathrm{H}_{2} \mathrm{O}\right)$ were added and the microplate was incubated at room temperature for 40 minutes. Absorbance was read at $415 \mathrm{~nm}$. Results were expressed as micrograms of quercetin equivalents per milligrams of extract.

\section{Antioxidant activity \\ 1. DPPH free radical-scavenging activity}

The free radical-scavenging activity was determined spectrophotometrically by means of DPPH assay [17]. Briefly, $40 \mu \mathrm{l}$ of $\mathrm{MeOH}$ solution of the sample at various concentrations was added to $160 \mu \mathrm{DPPH}(0.1 \mathrm{mM})$. The reaction mixture was shaken vigorously and the absorbance of remaining DPPH was measured at $517 \mathrm{~nm}$ after $30 \mathrm{~min}$. BHA and BHT were used as antioxidant standards for comparison of the activity. The scavenging capability of DPPH radical was calculated using the following equation:

$$
\text { DPPH scavenging effect }(\%)=\frac{\mathrm{A}_{\text {Control }}-\mathrm{A}_{\text {Sample }}}{\mathrm{A}_{\text {Control }}} \times 100
$$

The results were given as $\mathrm{IC}_{50}$ value $(\mu \mathrm{g} / \mathrm{ml})$ corresponding to the concentration of $50 \%$ inhibition.

\section{ABTS radical cation decolorization assay}

The spectrophotometric analysis of $\mathrm{ABTS}^{\bullet+}$ scavenging activity was determined according to the method of Re et al. [18]. After preparation of the oxidation solution of ABTS, the $\mathrm{ABTS}^{\circ+}$ solution was diluted to get an absorbance of $0.700 \pm 0.020$ at $734 \mathrm{~nm}$ with water. Then, $160 \mu \mathrm{l}$ of ABTS solution was added to $40 \mu \mathrm{l}$ of sample solution in methanol at different concentrations. After $10 \mathrm{~min}$., the absorbance was measured at $734 \mathrm{~nm}$. Methanol was used as a control. BHA and BHT were used as antioxidant standards for comparison of the activity. The results were given as the $\mathrm{IC}_{50}$ $(\mu \mathrm{g} / \mathrm{ml})$, which was calculated by means of the following equation:

$$
\mathrm{ABTS}^{\bullet+} \text { Scavenging effect }(\%)=\frac{\left(\mathrm{A}_{\text {Control }}-\mathrm{A}_{\text {Sample }}\right)}{\mathrm{A}_{\text {Control }}} \times 100
$$

\section{Reducing power assay}

The reducing power of the tested compounds was assessed according to the method of Bouratoua [19]. In order to determine the reducing power activity, $10 \mu$ of serial diluted sample were added into a 96 well round-bottomed plate. Following this, $40 \mu \mathrm{l}$ of $0.2 \mathrm{M}$ phosphate buffer ( $\mathrm{pH}$ 6.6) 
and $50 \mu \mathrm{l}$ of potassium ferricyanide (1\%), were added to each well and the plate was incubated at $50^{\circ} \mathrm{C}$ for $20 \mathrm{~min}$. Finally, $50 \mu \mathrm{l}$ of TCA(10\%) and distilled water $(40 \mu \mathrm{l})$ and $10 \mu \mathrm{l}$ of ferric chloride $(0.1 \%)$, was added into each well in order to measure the reducing power activity. The absorbance was measured in a microplate reader at $700 \mathrm{~nm}$. Higher absorbance of the reaction mixture indicates greater reducing power.

\section{Phenanthroline assay}

This test was carried out according to the method described by Szydłowska-Czerniak et al. [20]. $10 \mu \mathrm{l}$ of sample solution in methanol at different concentrations was placed into a 96 well round-bottomed plate. $50 \mu \mathrm{l}$ of $\mathrm{FeCl}_{3}$ $(0.2 \%)$ and $30 \mu \mathrm{l}$ of 1 , each well was then appended with 10-Phenanthroline $(0.5 \%)$. Finally, $110 \mu \mathrm{l}$ of methanol were added. The microplate was incubated 20 minutes at $30^{\circ} \mathrm{C}$ in a dark. The absorbance of solution was measured at $510 \mathrm{~nm}$. BHT and BHA were used as antioxidant standards.

\section{Cupric reducing antioxidant capacity (CUPRAC)}

The cupric reducing antioxidant capacity was determined according to the CUPRAC method [21]. In each well the reaction mixture containing $40 \mu \mathrm{l}$ of sample solution and $50 \mu \mathrm{l}$ of a copper (II) chloride solution, $50 \mu \mathrm{l}$ of neocuproine alcoholic solution, and $60 \mu \mathrm{l}$ of ammonium acetate aqueous buffer at $\mathrm{pH} 7$ was combined to give a final volume of $200 \mu \mathrm{l}$. After 30 minutes, the absorbance was measured at $450 \mathrm{~nm}$. Results were recorded as absorbance compared with the absorbance of BHA and BHT, which were used as antioxidant standards.

\section{Antioxidant capacity by the $\beta$-carotene bleaching assay}

The $\beta$-carotene bleaching activity of our compounds was evaluated using the $\beta$-carotene-linoleic acid system described by Marco [22]. Thus, a solution of $\beta$-carotene $(0.5 \mathrm{mg})$ in $1 \mathrm{ml}$ of chloroform is combined with $25 \mu \mathrm{l}$ of linoleic acid and $200 \mu \mathrm{l}$ of Tween 40 . After evaporation in vacuo of the chloroform, $50 \mathrm{ml}$ of Hydrogen peroxide $\mathrm{H}_{2} \mathrm{O}_{2}$ is added under vigorous agitation. The absorbance of the solution is then adjusted to $0.8-09 \mathrm{~nm}$. Amounts of $160 \mu \mathrm{l}$ of this solution are added to $40 \mu \mathrm{l}$ of solution of the studied synthetic compounds at different concentrations. The absorbance was measured at $470 \mathrm{~nm}$, using a 96-well microplate reader. The emulsion system was incubated for $2 \mathrm{~h}$ at $50^{\circ} \mathrm{C}$. A blank, devoid of $\beta$-carotene, was prepared for background subtraction. BHA and BHT were used as standards.

The bleaching rate $(\mathrm{R})$ of $\beta$-carotene was calculated according to the following equation:

$$
\mathrm{R}=\frac{\ln \mathrm{a} / \mathrm{b}}{\mathrm{t}}
$$

where: $\ln =$ natural $\log , \mathrm{a}=$ absorbance at time zero, $\mathrm{b}=$ absorbance at time t (120 $\mathrm{min})$.

The antioxidant activity (AA) was calculated in terms of percent of inhibition relative to the control, using following the equation:

$$
\mathrm{AA}(\%)=\frac{\mathrm{R}_{\text {Control }}-\mathrm{R}_{\text {Sample }}}{\mathrm{R}_{\text {Control }}} \times 100
$$

\section{Anticholinesterase activity}

Acetylcholinesterase (AChE) and butyrylcholinesterase (BChE) inhibitory activity was measured, by the spectrophotometric method developed by Ellman et al. [23]. Briefly, $150 \mu \mathrm{l}$ of $100 \mathrm{mM}$ sodium phosphate buffer ( $\mathrm{pH} 8.0$ ), $10 \mu \mathrm{l}$ of sample solution dissolved in methanol at different concentrations and $20 \mu \mathrm{l} \mathrm{AChE}\left(5.32 \times 10^{-3} \mathrm{U}\right)$ or $\mathrm{BChE}\left(6.85 \times 10^{-3} \mathrm{U}\right)$ solution were mixed and incubated for $15 \mathrm{~min}$ at $25^{\circ} \mathrm{C}$, and $10 \mu \mathrm{l}$ of $0.5 \mathrm{mM}$ DTNB [5,5'-dithio-bis(2-nitrobenzoic) acid] were added. The reaction was then initiated by the addition of $10 \mu \mathrm{l}$ of acetylthiocholine iodide $(0.71 \mathrm{mM})$ or butyrylthiocholine chloride $(0.2 \mathrm{mM})$. The hydrolysis of these substrates were monitored spectrophotometrically by the formation of yellow 5-thio-2-nitrobenzoate anion, as the result of the reaction of DTNB with thiocholine, released by the enzymatic hydrolysis of acetylthiocholine iodide or butyrylthiocholine chloride, respectively, at a wavelength of $412 \mathrm{~nm}$, every $5 \mathrm{~min}$ for $15 \mathrm{~min}$, utilising a 96-well microplate reader (Perkin Elmer Multimode Plate Reader, EnSpire, USA) in triplicate experiments. Galanthamine was used as reference compound. The results were given as $50 \%$ inhibition concentration $\left(\mathrm{IC}_{50}\right)$ and the percentage of inhibition of $\mathrm{AChE}$ or $\mathrm{BChE}$ was determined by comparison of reaction rates of samples relative to blank sample (methanol in phosphate buffer, $\mathrm{pH} 8$ ) using the formula:

$$
\text { inhibition of } \mathrm{AChE} \text { or } \mathrm{BChE}(\%)=\frac{\mathrm{E}-\mathrm{S}}{\mathrm{E}} \times 100 \text {, }
$$

where: $\mathrm{E}$ is the activity of enzyme without test sample, and $\mathrm{S}$ is the activity of enzyme with test sample.

\section{Statistical Analysis}

All data on antioxidant and anticholinesterase activities were the average of triplicate analyses. Data were recorded as the mean \pm standard deviation. Analysis of variance was executed using ANOVA test. Significant differences between means were determined by Tukey test; $p$ values $<0.05$ were regarded as significant. Pearson's correlation was calculated. All these tests were performed using XLSTAT 2014.

\section{RESULTS}

\section{Total phenolic and flavonoids content}

Results of total phenolic and flavonoids content of extracts are shown in Table 1.

Table 1. Total phenolic content (TPC) and total flavonoids content (TFC) of extracts of P. guajava.

\begin{tabular}{|l|c|c|}
\hline \multicolumn{1}{|c|}{ Extract } & $\mathrm{TPC}(\mu \mathrm{g} \mathrm{GAE} / \mathrm{mg})^{1}$ & $\mathrm{TFC}(\mu \mathrm{g} \mathrm{QE} / \mathrm{mg})^{2}$ \\
\hline Chloroform extract & $250.47 \pm 0.05$ & $112.71 \pm 0.09$ \\
\hline Ethyl acetate extract & $931.15 \pm 0.06$ & $269.57 \pm 0.10$ \\
\hline Butanol extract & $808.41 \pm 0.04$ & $68.37 \pm 0.03$ \\
\hline
\end{tabular}
Results are expressed as means \pm SD of three measurements
1 Micrograms of gallic acid equivalents per milligrams of extract
2 Micrograms of quercetin equivalents per milligrams of extract

The total content of phenols of leave extract of $P$. guajava was estimated by using the Folin-Ciocalteu method. The level of phenolic compounds in each fraction was expressed as micrograms of gallic acid equivalents per milligram 
of extract. Results showed that the ethyl acetate fraction contained the highest content $(931.15 \pm 0.06 \mu \mathrm{g} \mathrm{GAE} / \mathrm{mg})$, followed by the n-butanol fraction with $808.41 \pm 0.04 \mu \mathrm{g}$ $\mathrm{GAE} / \mathrm{mg}$. Chloroform extract gave the lowest result (250.47 $\pm 0.05 \mu \mathrm{g}$ GAE/mg). The total flavonoids content was determined by the trichloridealumiunm method and results were expressed as micrograms of quercetin equivalents per milligram of extract. Among the three extracts, the ethyl acetate fraction contained the highest amount $(269.57 \pm 0.10$ $\mu \mathrm{g} \mathrm{QE} / \mathrm{mg}$ ). Contrary to total phenolic content, flavonoids content of chloroform fraction was important with a value of $112.71 \pm 0.09 \mu \mathrm{g} \mathrm{QE} / \mathrm{mg}$. The minimum level of flavonoids was recorded by the n-butanol fraction $(68.37 \pm 0.03$ $\mu \mathrm{g} \mathrm{QE} / \mathrm{mg})$.

\section{Antioxidant properties}

The antioxidant activity of the different extracts from the leaves of Psidium guajava was evaluated using six different methods: DPPH radical scavenging [17], ABTS cation radicaldecolorization [18], Reducing power assay [19], Phenanthroline assay [20], CUPRAC [21], and $\beta$-carotene bleaching [22]. Results are shown in Table 2.

Table 2. DPPH radical scavenging, ABTS cation radical decolorization, Reducing power assay, Phenanthroline assay, CUPRAC, and $\beta$-carotene bleaching assays on extracts of P. guajava

\begin{tabular}{|c|c|c|c|c|c|c|}
\hline Samples & $\begin{array}{l}\mathrm{DPPH} \mathrm{IC}_{50} \\
\left(\mu \mathrm{g} \mathrm{ml}^{-1}\right)\end{array}$ & $\begin{array}{l}\text { ABTS IC }_{50} \\
\left(\mu \mathrm{g} \mathrm{ml}^{-1}\right)\end{array}$ & \begin{tabular}{|c|} 
Reducing \\
power $A_{0.5}$ \\
$\left(\mu \mathrm{ml}^{-1}\right)$
\end{tabular} & $\begin{array}{c}\text { Phen assay IC } \\
\left(\mu \mathrm{g} \mathrm{ml}^{-1}\right)\end{array}$ & $\begin{array}{c}\text { CUPRAC A } \\
\left(\mu \mathrm{g} \mathrm{ml}^{-1}\right)\end{array}$ & $\begin{array}{c}\beta \text {-carotene } \\
\text { bleaching IC } \\
\left(\mu \mathrm{g} \mathrm{m}^{-1}\right)\end{array}$ \\
\hline $\begin{array}{l}\text { Chloroform } \\
\text { extract }\end{array}$ & $>200$ & $>200$ & $>200$ & $\begin{array}{l}119.20 \\
\pm 1.85^{c}\end{array}$ & $>200$ & $\begin{array}{c}9.25 \\
\pm 1.26^{c}\end{array}$ \\
\hline $\begin{array}{l}\text { Ethyl acetate } \\
\text { extract }\end{array}$ & $\begin{array}{c}4.26 \\
\pm 0.05^{\mathrm{a}}\end{array}$ & $\begin{array}{c}5.25 \\
\pm 0.47^{\mathrm{b}}\end{array}$ & $\begin{array}{c}13.45 \\
\pm 5.82^{\mathrm{a}}\end{array}$ & $\begin{array}{c}3.25 \\
\pm 0.11^{\mathrm{b}}\end{array}$ & $\begin{array}{c}3.08 \\
\pm 0.55^{\mathrm{ab}}\end{array}$ & $\begin{array}{c}3.18 \\
\pm 0.10^{\mathrm{b}}\end{array}$ \\
\hline $\begin{array}{l}\text { Butanol } \\
\text { extract }\end{array}$ & $\begin{array}{c}5.48 \\
\pm 1.53^{\text {ab }}\end{array}$ & $\begin{array}{c}1.09 \\
\pm 0.10^{\mathrm{a}}\end{array}$ & $\begin{array}{l}26.63 \\
\pm 3.49^{\mathrm{b}}\end{array}$ & $\begin{array}{c}2.62 \\
\pm 0.01^{\mathrm{ab}}\end{array}$ & $\begin{array}{c}1.72 \\
\pm 0.06^{\mathrm{a}}\end{array}$ & $\begin{array}{c}3.53 \\
\pm 0.26^{\mathrm{b}}\end{array}$ \\
\hline BHA* & $\begin{array}{c}6.82 \\
\pm 0.49^{\mathrm{b}}\end{array}$ & $\begin{array}{c}1.03 \\
\pm 0.00^{\mathrm{a}}\end{array}$ & NT & $\begin{array}{c}0.93 \\
\pm 0.07^{a}\end{array}$ & $\begin{array}{c}3.64 \\
\pm 0.19^{\mathrm{b}}\end{array}$ & $\begin{array}{c}0.90 \\
\pm 0.02^{\mathrm{a}}\end{array}$ \\
\hline BHT* & $\begin{array}{l}22.32 \\
\pm 0.02^{c}\end{array}$ & $\begin{array}{c}1.59 \\
\pm 0.03^{\mathrm{a}}\end{array}$ & NT & $\begin{array}{c}2.24 \\
\pm 0.17^{\mathrm{ab}}\end{array}$ & $\begin{array}{c}9.62 \\
\pm 0.87^{c}\end{array}$ & $\begin{array}{c}1.05 \\
\pm 0.01^{\mathrm{a}}\end{array}$ \\
\hline $\begin{array}{l}\text { Ascorbic } \\
\text { acid * }\end{array}$ & NT & NT & $\begin{array}{c}6.77 \\
\pm 1.15^{\mathrm{a}}\end{array}$ & NT & NT & NT \\
\hline Tannic acid* & NT & NT & $\begin{array}{c}5.39 \\
\pm 0.91^{\mathrm{a}}\end{array}$ & NT & NT & NT \\
\hline
\end{tabular}

Results are expressed as means \pm SD of three measurements;

Analysis of variance (ANOVA) revealed significant effect $(p<0,05)$. The column means that share the same superscript letters are not significantly different; NT - Not tested * - Standards

The results revealed that the species Psidium guajava possesses important antioxidant activities at various degrees, in particularly the ethyl acetate and n-butanol fractions. Values of $\mathrm{IC}_{50}$ and $\mathrm{A}_{0.5}$ varied according to extract fraction. The chloroform extract showed weak antioxidant activity.

The DPPH radical is a stable lipophilic free radical and is always employed for evaluating the free radical scavenging potential of plant extract antioxidants [24]. DPPH radical scavenging, expressed as $\mathrm{IC}_{50}(\mu \mathrm{g} / \mathrm{ml})$ values, were compared to those of standards BHAand BHT. P. guajava exhibited a high DPPH scavenging ability. Therein, ethyl acetate and n-butanol extracts have greater inhibitory potential than did the standards, with $\mathrm{IC}_{50}=4.26 \pm 0.05 \mu \mathrm{g} / \mathrm{ml}$ and $\mathrm{IC}_{50}=5.48 \pm 1.53 \mu \mathrm{g} / \mathrm{ml}$, respectively.

$P$. guajava exhibited good activity in ABTS scavenging. Values of $\mathrm{IC}_{50}$ are very close to those of standards, especially the n-butanol fraction
$\left(\mathrm{IC}_{50}=1.09 \pm 0.10 \mu \mathrm{g} / \mathrm{ml}\right)$, which has an $\mathrm{IC}_{50}$ not significantly different to both that of BHA and BHT.

The reducing power activity of the samples was represented as $\mathrm{A}_{0.5}$ values. Compared to the standards (ascorbic acid and tannic acid), the best result was given by the Ethyl acetate fraction $\left(\mathrm{IC}_{50}=13.45 \pm 5.82 \mu \mathrm{g} / \mathrm{ml}\right)$. By contrast, the n-butanol fraction showed lower activity, with a $\mathrm{IC}_{50}$ value significantly different from that of the standards $(26.63 \pm 3.49$ $\mu \mathrm{g} / \mathrm{ml})$

Concerning the phenanthroline assay, results showed that ethyl acetate and n-butanol extracts had high activity, with values of $\mathrm{IC}_{50}$ close to the standards with a non- significant difference $\left(\mathrm{IC}_{50}=3.25 \pm 0.11 \mu \mathrm{g} / \mathrm{ml}\right.$ and $\mathrm{IC}_{50}=2.62 \pm 0.01$ $\mu \mathrm{g} / \mathrm{ml}$, respectively). The reduction of $\mathrm{Cu} 2+$ ions was evaluated by Cupric reducing antioxidant capacity (CUPRAC). This test gave very interesting results. Accordingly, ethyl acetate and n-butanol extracts of $P$. guajava showed a higher inhibition than that of BHA $\left(\mathrm{A}_{0.5}=3.08 \pm 0.55 \mu \mathrm{g} / \mathrm{ml}\right.$ and $\mathrm{A}_{0.5}=1.72 \pm 0.06 \mu \mathrm{g} / \mathrm{ml}$, respectively).

The only antioxidant activity where the chloroform fraction showed efficiency is in $\beta$-carotene bleaching inhibition. This fraction exhibited inhibitory activity, but the value of $\operatorname{IC}_{50}(9.25 \pm 1.26 \mu \mathrm{g} / \mathrm{m})$ was significantly different from standards. Ethyl acetate and n-butanol fractions were more efficient, with similar values of $\mathrm{IC}_{50}(3.18 \pm 0.10 \mu \mathrm{g} / \mathrm{ml}$ and $3.53 \pm 0.26 \mu \mathrm{g} / \mathrm{ml}$, respectively).

The correlation of total phenolic content with antioxidant activities is shown in Table 3. Results reveal high and negative correlation between the abundance of phenolic compounds and $\mathrm{IC}_{50}$ or $\mathrm{A}_{0.5}$ of several assays. The coefficient of correlation ( $\mathrm{r}$ ) is around -0.900 . As regards the total flavonoids content, the correlation is lower and negative.

\section{Anticholinesterase activity}

The colorimetric method of Ellman et al. [23] is based on determining the amount of thiocholine released when acetylthiocholine or butyrylthiocholine is hydrolysed by Acetylcholinesterase $(\mathrm{AChE})$ or Butyrylcholinesterase (BChE). The thiocholine released is quantified by its reaction with 5,5'-bisdithionitrobenzoic acid (DTNB), which produces a yellow 5-thio-2-nitrobenzoate anion [25].

The capacity of the samples to inhibit the cholinesterase was evaluated by the percentage of inhibition of $\mathrm{AChE}$ and $\mathrm{BChE}$ at various concentrations. The values of $\mathrm{IC}_{50}$ were compared to that of the galanthamine (Table 4).

Table 3. Pearson's correlations between total phenolic content (TPC), total flavonoids content (TFC) and antioxidant activities (DPPH, ABTS, Reducing power, Phen assay, CUPRAC, $\beta$-carotene bleaching), anticholinesterase activities (AChE, BChE)

\begin{tabular}{|c|c|c|c|c|c|c|c|c|c|}
\hline \multicolumn{2}{|c|}{} & $\begin{array}{c}\mathrm{I}_{50} \\
\text { DPPH }\end{array}$ & $\begin{array}{c}\mathrm{IC}_{50} \\
\text { ABTS }\end{array}$ & $\begin{array}{c}\mathrm{A}_{0.5} \\
\text { Reducing } \\
\text { power }\end{array}$ & $\begin{array}{c}\mathrm{IC}_{50} \\
\text { Phen } \\
\text { assay }\end{array}$ & $\begin{array}{c}\mathrm{A}_{0.5} \\
\text { CUPRAC }\end{array}$ & $\begin{array}{c}\mathrm{IC}_{50} \\
\text {-carotène } \\
\text { bleaching }\end{array}$ & $\begin{array}{c}\mathrm{IC}_{50} \\
\text { AChE }\end{array}$ & $\begin{array}{c}\mathrm{IC}_{50} \\
\text { BChE }\end{array}$ \\
\hline \multirow{2}{*}{ TPC } & $\mathrm{r}$ & -0.986 & -0.982 & -0.994 & -0.985 & -0.985 & -0.993 & -0.933 & -0.958 \\
\cline { 2 - 10 } & $\mathrm{R}^{2}$ & 0.973 & 0.965 & 0.989 & 0.970 & 0.969 & 0.986 & 0.871 & 0.919 \\
\hline \multirow{2}{*}{ TFC } & $\mathrm{r}$ & -0.312 & -0.290 & -0.367 & -0.303 & -0.302 & -0.356 & -0.114 & -0.192 \\
\cline { 2 - 9 } & $\mathrm{R}^{2}$ & 0.098 & 0.084 & 0.135 & 0.092 & 0.091 & 0.127 & 0.013 & 0.037 \\
\hline
\end{tabular}


Table 4. Inhibition of acetylcholinesterase (AChE) and (butyrylcholinesterase (BChE) by different extracts

\begin{tabular}{|c|c|c|c|c|c|c|}
\hline \multirow{3}{*}{ Samples } & \multicolumn{3}{|c|}{ AChE } & \multicolumn{3}{|c|}{ BChE } \\
\hline & \multicolumn{2}{|c|}{$\%$ inhibition } & \multirow{2}{*}{$\begin{array}{c}\mathrm{IC}_{50} \\
(\mu \mathrm{g} / \mathrm{ml})\end{array}$} & \multicolumn{2}{|c|}{$\%$ inhibition } & \multirow{2}{*}{$\begin{array}{c}\mathrm{IC}_{50} \\
(\mu \mathrm{g} / \mathrm{mL})\end{array}$} \\
\hline & $\begin{array}{c}100 \\
\mu \mathrm{g} /\left.\mathrm{m}\right|^{*}\end{array}$ & $\begin{array}{c}200 \\
\mu \mathrm{g} / \mathrm{ml}\end{array}$ & & $\begin{array}{c}100 \\
\mu \mathrm{g} / \mathrm{ml}\end{array}$ & $\begin{array}{c}200 \\
\mu \mathrm{g} / \mathrm{ml}\end{array}$ & \\
\hline $\begin{array}{l}\text { Chloroform } \\
\text { extract }\end{array}$ & $\begin{array}{l}36.42 \\
\pm 2.43 \\
\end{array}$ & $\begin{array}{l}53.52 \\
\pm 0.81\end{array}$ & $\begin{array}{l}177.11 \\
\pm 2.30^{\mathrm{d}} \\
\end{array}$ & NA & NA & $>200$ \\
\hline $\begin{array}{l}\text { Ethyl acetate } \\
\text { extract }\end{array}$ & $\begin{array}{l}82.42 \\
\pm 1.39\end{array}$ & $\begin{array}{l}96.99 \\
\pm 0.85\end{array}$ & $\begin{array}{c}56.11 \\
\pm 4.04^{c}\end{array}$ & $\begin{array}{l}61.65 \\
\pm 0.91\end{array}$ & $\begin{array}{l}95.65 \\
\pm 4.78\end{array}$ & $\begin{array}{c}44.95 \\
\pm 2.67^{b}\end{array}$ \\
\hline n-butanol extract & $\begin{array}{l}90.78 \\
\pm 5.32\end{array}$ & $\begin{array}{l}94.44 \\
\pm 3.10\end{array}$ & $\begin{array}{c}24.44 \\
\pm 3.45^{\mathrm{b}}\end{array}$ & $\begin{array}{l}91.01 \\
\pm 3.78\end{array}$ & $\begin{array}{l}94.88 \\
\pm 1.81\end{array}$ & $\begin{array}{c}21.87 \\
\pm 10.48^{\mathrm{a}}\end{array}$ \\
\hline Galanthamine** & $\begin{array}{l}91.80 \\
\pm 0.20\end{array}$ & $\begin{array}{l}94.77 \\
\pm 0.34\end{array}$ & $\begin{array}{c}6.27 \\
\pm 1.15^{\mathrm{a}}\end{array}$ & $\begin{array}{l}73.57 \\
\pm 0.77\end{array}$ & $\begin{array}{l}78.95 \\
\pm 0.58\end{array}$ & $\begin{array}{c}34.75 \\
\pm 1.99^{\mathrm{ab}}\end{array}$ \\
\hline
\end{tabular}

Results are expressed as means \pm SD of three measurements;

Analysis of variance (ANOVA) revealed significant effect $(p<0,05)$. The column means that share same superscript letters are not significantly different; NA - No activity;

${ }^{*}$ - Concentration is expressed as micrograms of extract per milliliter of methanol;

${ }^{* *}-$ Standard

P. guajava seems to have important anticholinesterase activity. The results showed a high percentage of inhibition of AChE at $100 \mu \mathrm{g} / \mathrm{ml}$ and $200 \mu \mathrm{g} / \mathrm{ml}$. The ethyl acetate and $n$-butanol extracts especially stood out, with values ranging up to $96.99 \%$ of inhibition (Fig. 1). Therein, $\mathrm{IC}_{50}$ of the two fractions was estimated at $56.11 \pm 4.04 \mu \mathrm{g} / \mathrm{ml}$ and $24.44 \pm 3.4 \mu \mathrm{g} / \mathrm{ml}$, respectively. The chloroform fraction had the highest $\mathrm{IC}_{50}(177.11 \pm 2.30 \mu \mathrm{g} / \mathrm{ml})$. This same species showed a very interesting power to inhibit the enzyme $\mathrm{BChE}$ at a rate going up to $95 \%$ (Fig. 2). The n-butanol extract gave an $\mathrm{IC}_{50}(21.87 \pm 10.48 \mu \mathrm{g} / \mathrm{ml})$ that was lower than that of galanthamine. Moreover, the difference between means was not significant. In contrast, the ethyl acetate fraction had

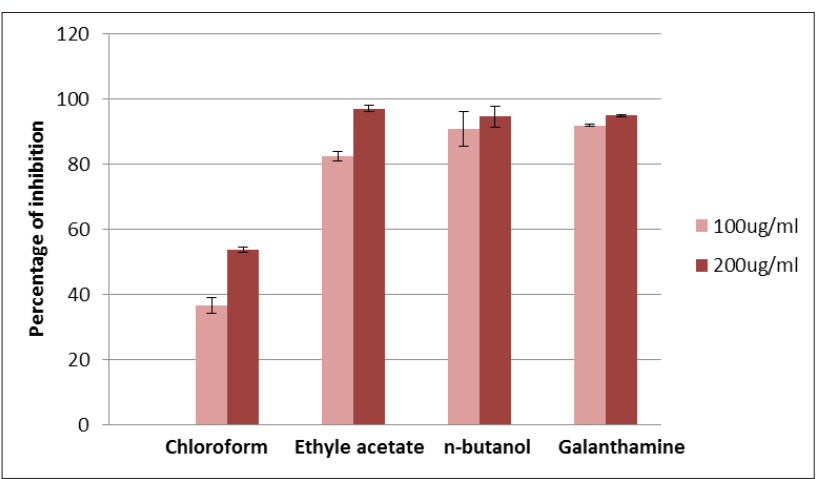

Figure 1. Percentage of inhibition of Acetylcholinesterase (AChE) at different concentrations of extract fractions of $P$. guajava and standard

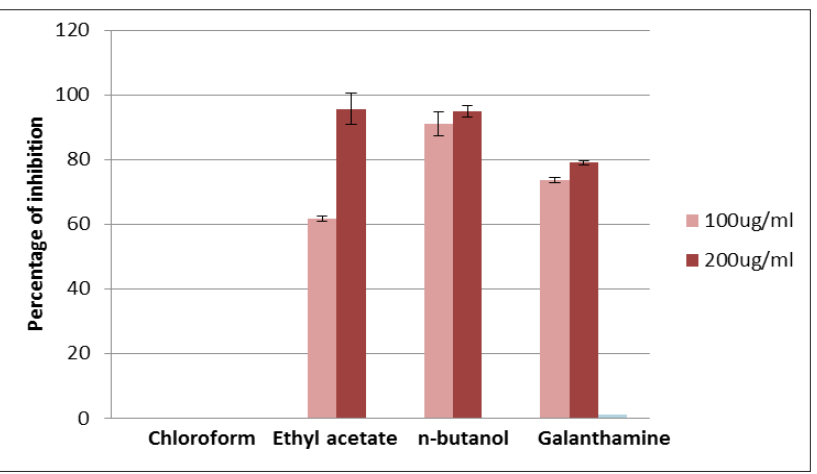

Figure 2. Percentage of inhibition of Butyrylcholinesterase (BChE) at different concentrations of extract fractions of $P$. guajava and standard an activity close to that of the standard $\left(\mathrm{IC}_{50}=44.95 \pm 2.67\right.$ $\mu \mathrm{g} / \mathrm{ml})$.

The correlation of total phenolic content with anticholinesterase activity is shown in Table 3 . Results revealed high and negative correlation between the abundance of phenolic compounds and the $\mathrm{IC}_{50}$ of both $\mathrm{AChE}$ and $\mathrm{BChE}$ tests, with $\left(r=-0.933, R^{2}=0.871\right)$ and $\left(r=-0.958, R^{2}=0.919\right)$, respectively. As regards the total flavonoids content, the correlation was lower and negative $\left(r=-0.114, R^{2}=0.013\right)$ and $\left(r=-0.192, R^{2}=0.037\right)$, respectively.

\section{DISCUSSION}

Our work shows elevated levels of phenolic compounds (TPC) and flavonoids (TFC), especially in the ethyl acetate fraction, followed by the n-butanol fraction. Chloroform contained the lowest rate. The results we attained are consistent with those of Mouffouk et al.[26] who found that the highest phenolic and flavonoids content were recorded in the ethyl acetate extract, followed by n-butanolic extract. Saeed et al. [27] have also noted similar results. The study of Babbar et al. revealed that ethyl acetate was better than the dichloromethane in extracting phenolic compounds and that polarity of extracting solvent might influence the TPC and TPC of the extracts [28]. The total phenolic and flavonoids content of $P$. guajava has been reported in many previous studies. Chang [29] recorded values of TPC $=229$ $\mu \mathrm{g} / \mathrm{mg}$ and $\mathrm{TFC}=208 \mu \mathrm{g} / \mathrm{mg}$ in aqueous guava budding leaf extract; these results are close to ours. In Brazil, a study on $P$. guajava leaves indicated a similar level in the ethanolic extract $(\mathrm{TPC}=766.08 \mu \mathrm{g} / \mathrm{mg}, \mathrm{TFC}=118.90 \mu \mathrm{g} / \mathrm{mg})[30]$. Another Brazilian study showed total flavonoid and polyphenol content of concentrated and spray-dried leaf extracts of P. guajava to be $(\mathrm{TPC}=25.93 \mu \mathrm{g} / \mathrm{mg}, \mathrm{TFC}=23.48 \mu \mathrm{g} / \mathrm{mg})$ [31]. Several other authors have confirmed the high level of phenol and flavonoids content in this species when grown in the Asian area [32-34].

Our results reveal that antioxidant activity and values of $\mathrm{IC}_{50}$ of some samples were lower than those of standards. This was the case for the DPPH radical scavenging assay and CUPRAC assay. These two tests are based on the capacity of antioxidant to transfer electrons. ABTS scavenging, Reducing power activity, Phenanthroline and $\beta$-carotene bleaching assays revealed results close to standards.

The $\beta$-carotene bleaching assay showed the activity of chloroform extract to be contrary to the other assays. This result is consistent with that of Hacibekiroglu and Kolak who found that chloroform extract induced high inhibition of lipid peroxidation as indicated by $\beta$-carotene bleaching assay, the effect being due to the presence of the phenolic and flavonoid compounds [35]. This antioxidant activity could be related to the abundance of phenolic compound in extracts. Extracts with a high level of total phenolic content showed best antioxidant capacities. Statistical results of correlation confirm this hypothesis with a very high coefficient of correlation between total phenolic content and all antioxidant assays.

Previous studies on leaf extracts of P. guajava reported a high degree of antioxidant activity that was due to richness in phenolic compounds. Qian et al. [36] found that different 
extracts from guava leaf showed good free radical-scavenging activity depending on the concentration used. Seo et al. [37] studied the antioxidant ability of water, ethanol and methanol extracts of $P$. guajava leaves, and their results demonstrated superior antioxidant ability of guava leaf extracts, albeit due more to phenolic compound content rather than flavonoid content. Another study on P. guajava leaves extract showed heightened antioxidant activity by way of using Ferum Reducing Power (FRAP) [38]. The aim of a recent Indonesian research was to evaluate antioxidant activity from ten species of Myrtaceae, including $P$. guajava. Herein, DPPH assay of ethyl acetate extract of $P$. guajava leaves gave $\mathrm{IC}_{50}=53.54 \pm 2.23 \mu \mathrm{g} / \mathrm{ml}$ - which was lower than that of Ascorbic acid [39]. These results are in accordance with ours, but the level of phenolic compounds was higher, The $\mathrm{IC}_{50}$ values we obtained were lower than most of the studies mentioned above and we also found greater antioxidant activities through all our assays. This difference could be explained by the fact that our plant material consisted of leaves of $P$. guajava which had acclimated and adapted to the local conditions of Algeria, hence, this differed to other studies on the same species grown in its natural environment (mainly in the Asian area, and within tropical and subtropical climates). Plant phenolics are well known to play crucial roles in plant ecology and physiology [40]. Studies that had gone before ours had investigated the role of phenolic compounds in the interactions of plants with various stress factors, with special attention to their antioxidant properties. Phenolic compounds play important roles in plant growth and development, particularly in defense mechanisms and adaptation to climatic conditions [41]. There is a potential, therefore, to use polyphenols as indicators of abiotic stress resistance [42].

Some studies associated antioxidant properties of P. gujava leaves with their phenolic compounds. Isolated compounds included ascorbic acid, gallic acid and caffeic acid [43], protocatechunic acid, ferulic acid, quercetin and guavin B [44], gallic acid, catechin, epicatechin, rutin, quercetin, naringenin and kaempherol [45]. The methanolic extract of Thai guava leaves has high antioxidant activity and three flavonoids with different levels of antioxidant power were isolated, quercetin, quercetin-3-O-glucopyranoside and morin [46].

The current study demonstrates the heightened inhibitory activity of ethyl acetate and n-butaol exacts of $P$. gujava leaves against both acetylcholinestrase (AChE) and butyrylcholinesterase (BChE). Herein, the chloroform extract showed interesting inhibition against $\mathrm{AChE}$, despite its weak antioxidant activity. These findings can be explained by the abundance in the chloroform extract of other bioactive compounds that exhibit inhibition of cholinesterase. Udoidong et al. [47] undertook a phytochemical screening of the chloroform extract of a medicinal species; the results of this revealed the presence of alkaloids, steroids, and flavonoids.

Studies analyzing the anticholinesterase activity of P. guajava species or even the genus Psidium are rare. Some research, however, has been done on other species of Myrtaceae. Gasca et al. [48] isolated two flavonoids, quercitin and catechin, from Eugenia dysenterica leaves.
These compounds exhibited superior acetylcholinesterase inhibitory effects, with $\mathrm{IC}_{50}=46.59 \pm 0.49 \mu \mathrm{g} / \mathrm{ml}$ and $42.39 \pm 0.67 \mu \mathrm{g} / \mathrm{ml}$ respectively. With regard to $P$. guajava, a previous study on thirteen Tai medicinal plants, including P. guajava, revealed that the latter's essential oils have no inhibitory effect on AChE [49]. In contrast, Indian research on P. guajava fruit showed that it produced significant reduction of brain acetylcholinesterase activity in young and aged mice. In the study, pretreatment of 15 days with P. guajava fruit protected the animals from developing memory deficits, and $P$. guajava fruit induced elevation of the brain acetylcholine level by significantly reducing acetylcholinesterase activity [50]. Our results on P. guajava leaves show the efficiency of this species as inhibitor of cholinesterase (AChE and $\mathrm{BChE}$ ). This effect could be related to its contained phenolic compounds and the resulting antioxidant activity.

The antioxidant effect of $P$. guajava fruit might also be beneficial in protecting the brains of rodents against oxidative stress [50]. A previous study confirmed the effect of quercetin on the acquisition and retention of spatial memory in a rat model of Alzheimer's disease and concluded that there is convincing evidence on the neuroprotective effects of flavonoids against Alzheimer's disease [51]. According to the studies cited above, P. guajava leaves contain quercitin.

\section{CONCLUSION}

Psidium guajava is a tree grown in tropical and subtropical regions where it is known for its medicinal properties. Our pioneering study focuses on P. guajava which has grown in a botanical garden in Algeria. A high level of total phenolic and flavonoid content was found. Therefore, extracts manifested antioxidant activities which were greater than the standards in some assays, notably DPPH scavenging and CUPRAC assays. The efficiency of P. guajava leaf extracts against Alzheimer's disease was also investigated by testing the inhibitory effect of the two enzymes acetylcholinesterase and butyrylcholinesterase. Results revealed that $P$. guajava extracts had values of $\mathrm{IC}_{50}$ close and even lower than the standard. We suppose that this important antioxidant activity is caused by the abundance of phenolic compounds produced unduly by leaves of our $P$. guajava trees through its acclimation and developed resistance to abiotic stress by way of manufacturing secondary metabolites. It should be noted that extracts with a high level of total phenolic content showed best antioxidant capacities.

As a perspective, ulterior study for isolation of those compounds could be realized. Chromatographic analysis would be necessary to identify these molecules. This species must undergo greater cultivation in Algeria as its bioactive molecules can be used as drugs and as an anti-Alzheimer remedy, though necessarily with the testing of other effects such as toxicity for safe use.

\section{ACKNOWLEDGEMENTS}

We are grateful to Mr Chalabi, the agronomist in charge of the Botanical Garden of the University of Skikda for his help and generosity.

We also thank all the staff of the laboratories (qualityanalysis) and (biochemistry) at the Biotechnology Research 
Center of Constantine, Algeria, for their welcome and availability.

\section{ORCID iDs}

Imane Bouchoukh (Dhttps://orcid.org/0000-0003-1808-5519 Tahar Hazmoune Dhttps://orcid.org/0000-0003-0969-9455 Mokhtar Boudelaa (Dhttps://orcid.org/0000-0001-5360-9133 Chawki Bensouici Dhttps://orcid.org/0000-0003-4612-4642 Amar Zellagui (Dhttps://orcid.org/0000-0002-6515-8103

\section{REFERENCES}

1. Yoshikawa T, Naito Y. What Is Oxidative Stress? J Am Vet Med Assoc. 2002;45(7):271-6.

2. Saxena M, Saxena J, Pradhan A. Flavonoids and phenolic acids as antioxidants in plants and human health. Int J Pharm Sci Rev Res. 2012;16(2):130-4.

3. Verdile G, Keane KN, Cruzat VF, Medic S, Sabale M, Rowles J. et al. Inflammation and Oxidative Stress: The Molecular Connectivity between Insulin Resistance, Obesity, and Alzheimer's Disease. Mediators Inflamm. 2015:1-17.

4. EtindelSosso FA, Nakamura O, Nakamura M. Epidemiology of Alzheimer's disease: Comparison between Africa and South America. J Neurol Neuro Sci. 2017;8:3.

5. Augustinsson KB. Comparative Aspects of the Purification and Properties of Cholinesterases. B World Health Organ. 1971;44(1-2-3): 79-89.

6. Kim D, Jeond S, Lee C. Antioxidant capacity of phenolic phytochemicals from various cultivars of plums. Food Chem. 2003; 81:321-6.

7. Juanda D, Aligita W, Elfahmi, Hartati R, Musaad S. Antioxidant and alpha glucosidase inhibition activity of kupa (Syzygium polychepalum Miq.) cortex. Int J Pharm Phytopharm Res. 2018;8(3):33-8.

8. Mahbubur Rahman HM. ,Zaman R. Taxonomy and Traditional Medicinal Plant Species of Myrtaceae (Myrtle) Family at Rajshahi District, Bangladesh. Int J Adv Res. 2015;3(10):1057-66.

9. El-Ahmady SH, Ashour ML, Wink M. Chemical composition and anti-inflammatory activity of the essential oils of Psidium guajava fruits and leaves. J Essent Oil Res. 2013;25(6):475-81.

10. Rojas-Garbanzo C. Psidium Fruits: Endemic fruits of latin America with a wide variety of phytochemicals. Clin Oncol. 2018;3:1479.

11. Hamada S, Kitanaka S. Method of treatment of atopic dermatitis with dried guava leaves. United States Patent. 1999;5:231.

12. Gutierrez RM, Mitchell S, Solis RV. Psidium guajava: A review of its traditional uses, phytochemistry and pharmacology. J Ethnopharmacol. 2008;117(1):1-27.

13. Chalabi R. Espèces fruitières de l'ancienne école d'agriculture de Skikda: Recensement et sauvegarde. Mémoire de magistère en Agronomie : University of Skikda, Algeria. 2014; p. 103.

14. Singleton VL, Rossi, JA. Colorimetry of total phenolics with phosphomolybdicphosphotungstic acid reagent. Am J Enol Vitic. 1965;16;144-58.

15. Muller L, Gnoyke S, Popken AM, Bohm V. Antioxidant capacity and related parameters of different fruit formulations. LWT-Food Sci Technol. 2010;43(6):992-9.

16. Topçu G, Ay A, Bilici A, Sarıkürkcü C, Öztürk M, Ulubelen A. A new flavone from antioxidant extracts of Pistacia terebinthus. Food Chem. 2007;103(3):816-22.

17. Blois MS. Antioxidants determination by the use of a stable free radical. Nature. 1958;26:1199-200.

18. Re R, Pellegrini N, Proteggente A, Pannala A, Yang M, Rice-Evans C. Antioxidant activity applying an improved ABTS radical cation decolorization assay. Free Radic Biol Med. 1999;26(9-10):1231-7.

19. Bouratoua A, Khalfallah A, Bensouici C, Kabouche Z, AlabdulMagi A, Harakat D. et al. Chemical composition and antioxidant activity of aerial parts of Ferula longipes Coss. ex Bonnier and Maury. Nat Prod Res. 2017;32(16):1873-80.

20. Szydłowska-Czerniak A, Dianoczki C, Recseg K, Karlovits G, Szłyk E. Determination of antioxidant capacities of vegetable oils by ferric-ion spectrophotometric methods. Talanta. 2008;76(4):899-905.
21. Apak R, Güçlü K, Ozyürek M, Karademir SE. Novel total antioxidant capacity index for dietary polyphenols and vitamins $\mathrm{C}$ and $\mathrm{E}$, using their cupric ion reducing capability in the presence of neocuproine: CUPRAC method. J Agric Food Chem. 2004;52 (26):7970-81.

22. Marco GJ. A rapid method for evaluation of antioxidants. J Am Oil Chem Soc. 1968;45, 594-8.

23. Ellman GL, Courtney D, Andies V, Featherstone RM. A new and rapid colorimetric determination of acetylcholinesterase activity. Biochem Pharmacol. 1961;7, 88-95.

24. Xiaoyong S, Luming C. Phenolic constituents, antimicrobial and antioxidant properties of blueberry leaves (V5). J Food Nutr Res. 2014;2(12):973-9.

25. Adewusi E. A, Moodley N, Steenkamp V. Medicinal plants with cholinesterase inhibitory activity: A Review. Afr J Biotechnol. 2010;9(49):8257-76.

26. Mouffouk C, Hambaba L, Haba H, Mouffouk S, Bensouici C, Mouffouk S. et al. Acute toxicity and in vivo anti inflammatory effects and in vitro antioxidant and anti arthritic potential of Scabiosa stellate. Orient Pharm Exp Med. 2018;8(5).

27. Saeed N, Khan MR, Shabbir M. Antioxidant activity, total phenolic and total flavonoid contents of whole plant extracts Torilisleptophylla L. BMC Complement Altern Med. 2012;12:221.

28. Babbar N, Oberoi HS, Sandhu SK, Bhargav VK. Influence of different solvents in extraction of phenolic compounds from vegetable residues and their evaluation as natural sources of antioxidants. J Food Sci Technol. 2012;51(10):2568-75.

29. Chang YS. The bioactive constituents of aqueous guava budding leaf extract and their apoptotic mechanism on DU145 prostate cancer cells, M.S. thesis, Research Institute of Biotechnology: Hungkuang University.

30. Vieira Braga T, Gonçalves Rodrigues das Dores R, Soncin Ramos C, Gontijo Evangelista FC, Márcia da Silva Tinoco L, de PillaVarotti F. et al. Antioxidant, antibacterial and antitumor activity of ethanolic extract of the Psidium guajava leaves. Am J Plant Sci. 2014;5:3492-500.

31. Fernandes MRV, Dias ALT, Carvalho RR, Souza CRF, Oliveira WP. Antioxidant and antimicrobial activities of Psidium guajava L. spray dried extracts. Ind. Crops Prod. 2014;60:39-44.

32. Kawakami Y, Nakamura T, Hosokawa T, Suzuki-Yamamoto T, Yamashita H, Kimoto M, et al. Antiproliferative activity of guava leaf extract via inhibition of prostaglandin endoperoxide $\mathrm{H}$ synthase isoforms. Prostaglandins Leukot Essent Fatty Acids. 2009;80(5-6):239-45.

33. Chen KC, Hsieh CL, Huang KD, Ker YB, Chyau CC, Peng RY. Anticancer activity of rhamnoallosan against DU-145 cells is kinetically complementary to coexisting polyphenolics in Psidium guajava budding leaves. J. Agric. Food Chem. 2009;57(14):6114-22.

34. Jang M, Jeong S.W, Cho SK, Ahn KS, Kim BK, Kim JC. Anti-inflammatory effects of 4 medicinal plant extracts in lipopolysaccharide-induced RAW 264.7 cells. Food Sci Biotechnol. 2013;22(S):213-20.

35. Hacibekiroglu I, Kolak U. Screening antioxidant and anticholinesterase potential of Iris albicans extracts. Arab J Chem. 2015;8(2): 264-8.

36. Qian H, Nihorimbere V. Antioxidant power of phytochemicals from Psidium guajava leaf. J Zhejiang Univ Sci. 2004;5(6):676-83.

37. Seo J, Lee S, Elam ML, Johnson SA, Kang J, Arjmandi BH. Study to find the best extraction solvent for use with guava leaves (Psidium guajava L.) for high antioxidant efficacy. Food Sci Nutr. 2014;2(2):174-80.

38. Norhidayah A, Babji AS, Shazali MS, Norazmir MN, Norazlanshah H. Effects of Mango (Mangifera indica L.) and Guava (Psidium guajava L.) Extract on Frozen Chicken Meat Balls' Storage Quality. Pak J Nutr. 2011;10(9):879-83.

39. Ramadhania ZM, Insanu M, Gunarti NS, Wirasutisna KR, Sukrasno S, Hartati R. Antioxidant activity from ten species of Myrtaceae. Asian J Pharm Clin Res. 2017; Special issue:5-7.

40. Roseiro LB, PilarRauter A, MouratoSerralheirob ML. Polyphenols as acetylcholinesterase inhibitors: Structural specificity and impact on human disease. J Nutr Aging. 2012;1(2):99-111.

41. Kulbat $\mathrm{K}$. The role of phenolic compounds in plant resistance. Biotechnol Food Sci. 2016;80 (2):97-108 
42. Cheruiyot EK, Mumera LM, Ngetich WK, Hassanali A, Wachira F. Polyphenols as potential indicators for drought tolerance in tea (Camellia sinensis L.). Biosci Biotechnol Biochem. 2007;71(9):2190-7.

43. Jimenez EA, Rincon M, Pulido R, Saura CF. Guava fruit as a new source of antioxidant dietary fibre. J Agric Food Chem. 2001;49: 5489-93.

44. Thaipong K, Boonprakob U, Cisneros-Zevallos L, Byrne DH. Hydrophilic and lipophilic antioxidant activities of guava fruits. Southeast Asian J Trop Med Public Health. 2005;36(S4):254-7.

45. Hsieh CL, Huang CN, Lin YC, Peng RY. Molecular action mechanism against apoptosis by aqueous extract from guava budding leaves elucidated with human umbilical vein endothelial cell (HUVEC) model. J Agric Food Chem. 2007;55(21):8523-33.

46. Tachakittirungrod S, Ikegami F, Okonog S. Antioxidant Active Principles Isolated from Psidium guajava Grown in Thailand. Sci Pharm. 2007;75(4):179-93.

47. Udoidong AA, Etuk BA, Udo IE. Phytochemical and chromatographic analysis of chloroform extract of Marsdenia latifelia. Adv Appl Sci Res. 2014;5(1):53-8.
48. Gasca CA, Castillo WO, Takahashi CS, Fagg CW, Magalhaes PO, Fonseca-Bazzo YM. et al. Assessment of anti-cholinesterase activity andcytotoxicity of cagaita (Eugenia dysenterica) leaves. Food Chem Toxicol. 2017;109(Pt 2):996-1002.

49. Kitphati W, Wattanakamolkul K, Lomarat P, Phanthong P, Anantachoke N, Nukoolkarn V. et al. Anticholinesterase of essential oils and their constituents from Thai medicinal plants on purified and cellular enzymes. JAASP. 2012;1(1):58-67.

50. Parle M, Broka E. Guava: A promising memory enhancer in rodents. Int J Plant Sci. 2010;5(1):297-301

51. Ashrafpour M, Parsaei S, Sepehri H. Quercetin improved spatial memory dysfunctions in rat model of intracerebroventriculars treptozotocin-induced sporadic Alzheimer'sdisease. Natl J Physiol Pharm Pharmacol. 2015;5(5):411-5. 